\title{
Boron-Mediated Plant Somatic Embryogenesis: A Provocative Model
}

\author{
Dhananjay K. Pandey, Arvind K. Singh, and Bhupendra Chaudhary
}

School of Biotechnology, Gautam Buddha University, Greater Noida 201 308, India

Correspondence should be addressed to Bhupendra Chaudhary, bhupendrach@gmail.com

Received 5 May 2012; Revised 30 June 2012; Accepted 9 August 2012

Academic Editor: Philip J. White

Copyright (C) 2012 Dhananjay K. Pandey et al. This is an open access article distributed under the Creative Commons Attribution License, which permits unrestricted use, distribution, and reproduction in any medium, provided the original work is properly cited.

\begin{abstract}
A central question in plant regeneration biology concerns the primary driving forces invoking the acquisition of somatic embryogenesis. Recently, the role of micronutrient boron (B) in the initiation and perpetuation of embryogenesis has drawn considerable attention within the scientific community. This interest may be due in part to the bewildering observation that the system-wide induction of embryogenic potential significantly varied in response to a minimal to optimal supply of B (minimal $\leq$ $0.1 \mathrm{mM}$, optimal $=0.1 \mathrm{mM}$ ). At the cellular level, certain channel proteins and cell wall-related proteins important for the induction of embryogenesis have been shown to be transcriptionally upregulated in response to minimal B supply suggesting the vital role of $\mathrm{B}$ in the induction of embryogenesis. At the molecular level, minimal to no B supply increased the endogenous level of auxin, which subsequently influenced the auxin-inducible somatic embryogenesis receptor kinases, suggesting the role of B in the induction of embryogenesis. Also, minimal B concentration may "turn on" other genetic and/or cellular transfactors reported earlier to be essential for cell-restructuring and induction of embryogenesis. In this paper, both the direct and indirect roles of B in the induction of somatic embryogenesis are highlighted and suggested for future validation.
\end{abstract}

\section{Introduction}

1.1. Somatic Embryogenesis in Plants. In plants, somatic embryogenesis is a multistep and complex regeneration process which begins with the formation of proembryonic mass followed by somatic embryo initiation, maturation, and, ultimately, entire plantlet regeneration [1]. Mostly, it refers to the developmental plasticity characteristic of the differentiated cells to regain their totipotency and convert into embryos. In theory, each somatic cell has the potential to convert itself into a somatic embryo, though very few somatic cells are capable of undergoing such complicated morphological transformation under culture conditions. In fact, only certain plant taxa and selected explants types have been shown to be capable of inducing embryogenic potential with in vitro cultures. As a result of these complicating factors, knowledge of how to "switch on" all somatic cells with such embryogenic potential is quite limited.

Since the initial descriptions of in vitro somatic embryogenesis $[2,3]$, one important characteristic of somatic embryos is the continuous growth resulting from the absence of developmental arrest [4]. In general, the process has three different stages of embryo development: globular, heart-shaped, and torpedo-shaped stages in dicots; globular, scutellar (transition), and coleoptilar stages in monocots $[5,6]$. Again, although each plant cell has the competence to undergo somatic embryogenesis, the acquisition of embryogenic potential is extremely complex and involves intricate genetic mechanisms which are influenced by multiple factors [1]. Here, we strive to answer the question of what factors may be the most important in the induction of embryogenesis in plants. Are there different developmental and genetic conditions providing pertinent microenvironment for the acquisition of embryogenic potential?

The current literature on plant regeneration studies highlighted that the factors considered to be responsible for the induction of somatic embryogenesis are highly incoherent and largely dependent upon plant genotype/cultivar, tissuetype, physiological conditions of the donor plant, and varied 
cultural regimes [6]. Methodologically, the induction of embryogenic state in the somatic cells may include exposure to plant growth regulators and various physical and chemical treatments, and more precisely, it is often accompanied with cellular stress milieu $[7,8]$. Therefore, what could be the most prevalent target procedures for the initiation of such stress conditions? For example, the exogenous auxin $(2,4-\mathrm{D})$ has been used for the upregulation of several stress-induced genes to initiate somatic embryo development across plant taxa $[9,10]$. If so, are the hormonal conditions most prevalent in the induction of somatic embryogenesis in plants? Moreover, to induce somatic embryogenesis, the endogenous level of auxin has also been influenced through the manipulation in the cumulative effect of micro- and macronutrient in vitro. So, is there any direct role of micromineral nutrition in the process of somatic embryogenesis, or indirectly via changing the endogenous hormonal levels those which are largely unexplored hitherto? An interesting example is the supply of micronutrient boron (B) in vitro in the form of boric acid which appears to be an important factor in the initiation of somatic embryogenesis [11-14].

1.2. Boron: An Essential Nutrient with Diverse Functions. B has been categorized as one of the essential micronutrients for the growth and development of vascular plants [15]. Boron is necessary for very diverse physiological processes such as the synthesis and organization of the cell wall and cell membrane structure [15-18], phenylpropanoid metabolism, and lignin biosynthesis $[19,20]$. Across biological systems, B is known to influence pollen tube growth [21], nucleic acid metabolism [22, 23], polysaccharide metabolism [12, 24, 25], auxin metabolism [26, 27], and nitrate reductases activity $[28,29]$. Plant response to B-mediated stress conditions is highly diverse and can vary based on the species, tissues, and physiological and environmental conditions [21].

Although within the plant, B is found to be most heavily concentrated in the cell wall [30]; it might also play a pivotal role in a wide variety of other cellular processes such as induction of somatic embryogenesis. This incites our convictions that if large concentration of $\mathrm{B}$ is positioned in the cell wall and cell membrane, are these the actual sites associated directly or indirectly with the induction of somatic embryogenesis? However, this has to be explored in depth experimentally to clearly define the role of B-associated cell walls in the induction of embryogenic potential. Aside from the cell wall, B has been observed to be present in other parts of the plant cell. Using stable isotopes $11 \mathrm{~B}$ and 10B, the intracellular compartmentation of $\mathrm{B}$ in the roots of sunflower has been examined in vitro on relatively high and low B concentrations [31]. Though the B supply varied up to 100 -fold in two different culture regimes, the accumulation of B in the cytosol and vacuole of low B-supplemented plants was $66 \%$ and $37 \%$ of the respective accumulation in the high B-supplemented plants. Thus, the presence of B in different cell organelles suggests additional roles of B in plant metabolism aside from its major function in cell wall organization [31]. Therefore, is B also having a role in the initiation and perpetuation of embryogenesis?
A bewildering observation from previous studies is that different plant systems do not respond in the same manner to varied concentrations (ranging from minimal to optimal) of $B$ for the induction of somatic embryogenesis. Here, we suggest a scale for the $\mathrm{B}$ concentration supplied in vitro for somatic embryogenesis, where minimal $\leq 0.1 \mathrm{mM}$, optimal $=0.1 \mathrm{mM}$, maximal $=0.1-1.0 \mathrm{mM}$, and toxic $\geq 1.0 \mathrm{mM}$ (the $\mathrm{B}$ concentrations are followed by these terms, hereafter) [3234] (Figure 1). For example, in rice using coleoptiles or scutellum explants, the supplementation of optimal B concentration showed utmost somatic embryogenesis, whereas least somatic embryogenesis was observed with the maximal $\mathrm{B}$ concentration while using root tissues. Also, the optimal $\mathrm{B}$ concentration has direct influence on the development of suspensor of the somatic embryos in Larix decidua, whereas minimal B concentration led to the inhibition of suspensor development [35, 36]. Conversely, Mashayekhi et al. [32] reported in cucumber that minimal B concentration induced maximum somatic embryogenesis. Since B concentration required for the induction of somatic embryogenesis varied significantly among different explant types even from the same species, it becomes extremely challenging to suggest a standard B concentration required for the induction of somatic embryogenesis across plant taxa. In such changeable scenario, it would be difficult to develop a molecular network of cellular processes during B-mediated somatic embryogenesis.

Essentially, a minimal (to optimal) amount of B (Figure 1) appears to trigger somatic embryogenesis utmost among plant species having an impact on the cell wallmediated signalling. Although these results have enriched our understanding to an extent, further experimental work is required to explore the intricacies of B-mediated downstream regulation of somatic embryogenesis in different biological systems. In this review, the role of B in the induction of somatic embryogenesis is thoroughly reviewed and hypothesized at times for future experimental validation.

\section{Abundant Channel Protein Expression during Early Somatic Embryogenesis for Optimal B Mobility}

In the cell membrane, different channel proteins are responsible for the transport of the various moieties required for cellular growth and metabolism. Aquaglyceroporins (AqGPs) are the pore proteins (coded by NIP) which facilitate efficient and selective flux of small solutes across biological membranes and are also responsible for the transport of B into the cytoplasm [39] (Figure 2). It has been observed that NIPs show a high degree of substrate specificity [40], for example, in Arabidopsis, it has been clearly illustrated that there are two subgroups in the NIP family, and only subclass II is responsible for the transportation of boric acid inside the cell [41]. It has been assumed that these pore proteins are important for the initiation of somatic embryogenesis mainly through the supply of micronutrients in the cytoplasm. Ciavatta et al. [42] also implicated abundantly expressed AqGPs in early embryo 


$\begin{array}{ccccc}\text { Category } & \text { Minimal } & \text { Optimal } & \text { Maximal } & \text { Toxic } \\ \text { B concentration } & {[\leq 0.1 \mathrm{mM}]} & {[0.1 \mathrm{mM}]} & {[0.1-1 \mathrm{mM}]} & {[\geq 1 \mathrm{mM}]} \\ (\mathrm{mM}=\text { milimolar }) & & (\text { MS medium }) & \end{array}$

FIgURE 1: The proposed scale of B concentration used for plant tissue culture and induction of somatic embryogenesis in different genotypes. Varied concentrations of B are broadly categorized into four groups ranging from minimal to toxic. The "optimal" category of B concentration is depicted as the concentration proposed in the MS medium [37] that is widely used for plant regeneration studies.

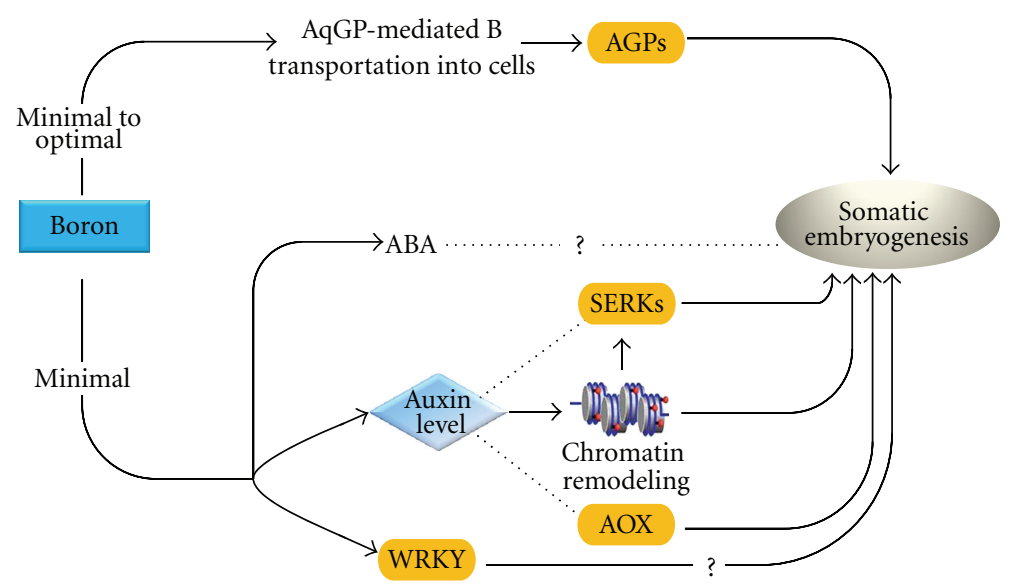

Figure 2: A hypothetical model based on the results shown for the involvement of boron on plant somatic embryogenesis. The putative candidate genes and biological processes upregulated in response to boron supplementation are highlighted. The minimal and optimal supplies of boron activate different transcription factors, hormones, and other cellular proteins known to be responsible for the induction of embryogenic potential in the cell (see text for details).

development in loblolly pine. The high expression level of NIP1;1 has been observed to be conserved in early somatic and zygotic embryo stages [42]. Further, it has also been shown in Arabidopsis that the major intrinsic protein NIP5;1 is essential for efficient $B$ uptake during plant development. Under relatively low B condition, NIP5;1 gene is upregulated in the root elongation zone and the root hair zone, indicating its direct and crucial role in B maintenance during cellular development. However, in NIP5;1 mutant lines, the reduced mRNA level of NIP5; 1 gene at a relatively low B concentration suggests the $\mathrm{B}$-dependent transcriptional regulation of the NIP5;1 gene [43]. Conversely, toxic levels of B degrade the mRNA coding for AqGPs, preventing the cell from B toxicity [44]. Thus, it may be concluded that B uptake is maintained by the expression of intrinsic channel proteins, which may be influencing early embryogenic processes. It may be argued here that boric acid can be transported into cell via passive diffusion across membrane bilayers, and AqGP is essentially not needed when B is supplied more than an optimal level $(>100 \mu \mathrm{M})$. For example, a toxic concentration of $\mathrm{B}$ (more than $1 \mathrm{mM}$ ) significantly decreased the embryogenic potential, which suggests that the excess B is supplied to the cell through diffusion and not through channel proteins [33]. Therefore, AqGPs may only be affecting somatic embryogenesis positively only under relatively low (minimal) B supply.

In such scenario, is there any relationship between specific histological patterns (cell wall) of normal versus embryogenic cells and also the mode of B supply opted by any such cell? And is the transcript pattern of NIPs localized or varies across species? If so, characterization of embryogenic potential of any particular cell could be directly measured through the expression patterns of NIPs. Currently, it is a question requiring further study whether varied exogenous supply of B will influence the NIP transcript levels, and if it is also responsible for the conversion of normal cells into embryogenic cells. This research effort is being carried out by the authors with cotton (Gossypium hirsutum cv. Coker 310 ) due to its history as an established model system for in vitro somatic embryogenesis (Figure 3) [38]. In cotton, the somatic embryogenesis process begins with the initial callusing phase followed by the secondary growth phase that provides a suitable platform for the induction of embryogenic calli. Preliminary results from this study highlight that minimal B supply induces more embryogenesis in cotton cultures than that of optimal B supply (data not shown).

Therefore, it may be hypothesized that NIPs are important for a significant amount of B transport (required for embryogenesis) into the cell, and that as a result, this may also increase levels of AqGPs in the cell membrane. Higher levels of AqGPs may further increase the regeneration potential of somatic cells and ultimately incite somatic embryogenesis (Figure 4). At present, though several interrelated issues important to understanding the precise mechanism of embryogenesis remain unclear and unresolved, yet it may certainly be hypothesized that B-mediated expression of AqGPs plays a vital role in the induction of somatic embryogenesis. 


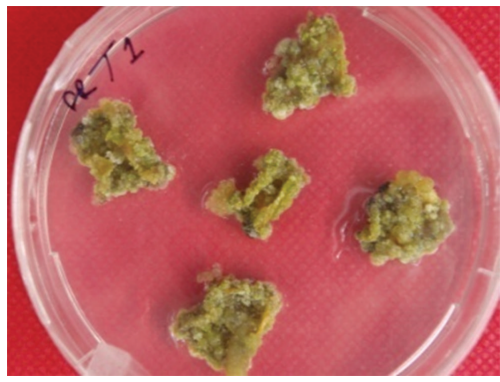

(a)

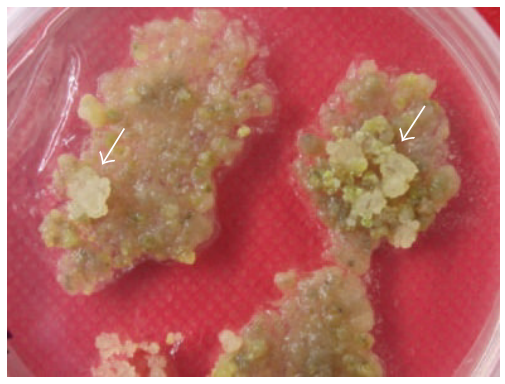

(c)

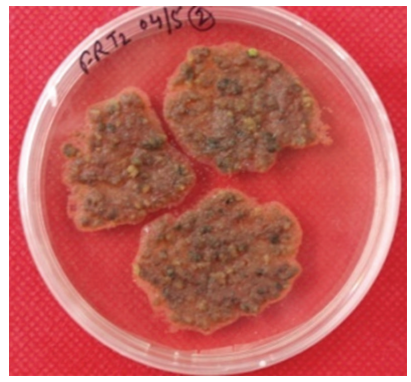

(b)

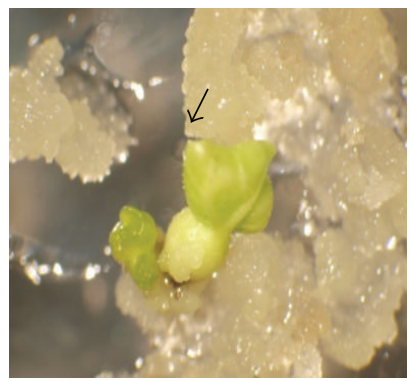

(d)

FIGURE 3: Developmental stages of somatic embryogenesis in the genus Gossypium, an established model system for indirect somatic embryogenesis [38]. It involves three major stages: (a) initial callus induction, (b) middle callus growth, and (c) late embryogenic callus induction phase. (d) Fully-grown somatic embryos are developed from the embryogenic callus. The cotton cotyledonary explants were used for initial callus initiation followed by the induction of embryogenic calli (shown by white arrows) and eventually leading to the development of somatic embryos (shown by black arrow).

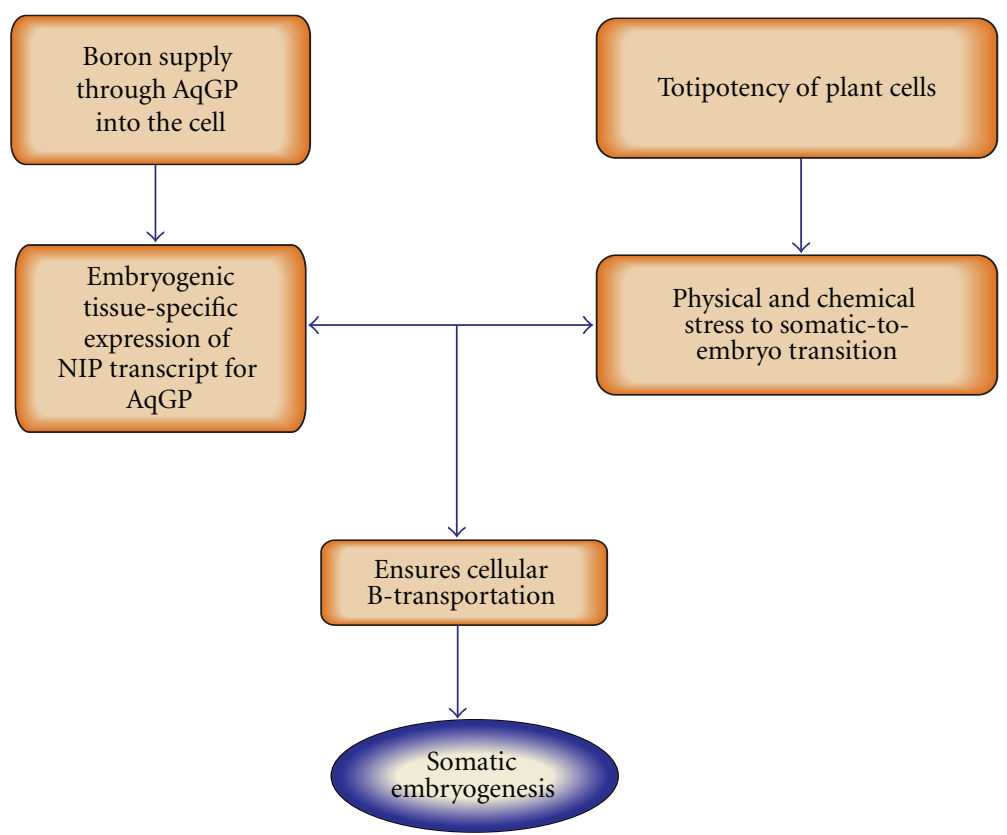

FIGURE 4: Diagrammatic representation of the putative role of AqGPs (NIP) in somatic embryogenesis. 


\section{Boron Regulates Cell Wall-Related Genes during Somatic Embryogenesis}

In general, somatic cells that are competent for the acquisition of embryogenic potential perceive signals from neighbouring cells to trigger somatic embryogenesis and arabinogalactan proteins (AGPs) have been identified to initiate such signals [45]. AGPs are a heterogeneous group of structurally complex macromolecules composed of a polypeptide, a large branched glycan chain, and a lipid [46]. These proteins remain present in the cell wall and plasma membrane, functioning at the cell surface to mediate signal transduction via the cell wall-plasma membrane-cytoskeleton continuum [47], which is an essential structural assembly involved in the growth and morphogenesis of higher plants [48]. The structure and function of these proteoglycans are currently of intense interest as there is direct evidence for their involvement in the induction of embryogenesis $[49,50]$. The spatiotemporal expression of AGPs has been reported during differentiation of globular stage somatic embryos into torpedo stage embryos in somatic embryogenesis [51]. It may be argued here that during the induction of embryogenesis, will the somatic cells devoid of any AGPs elude its embryogenic competence?

Thompson and Knox [52] and Chapman et al. [51] have shown in Daucus carota and Cichorium hybrid "474" that scavenging cellular AGPs, through addition of "Yariv" reagent in tissue culture media, inhibit somatic embryogenesis; exogenous addition of AGPs restores such potential, even to the point of significantly increasing somatic embryogenesis. For example, an up to 60 -fold increase of somatic embryogenesis was observed in carrot by the addition of activated AGP [53]. These results show that activated AGPs are the extracellular matrix molecules that control and maintain plant cell fate during somatic embryogenesis. Given the important role of AGPs in somatic embryogenesis, what are the essential factors in the cell that maintain the endogenous AGPs level for this complex process to occur?

Interestingly, data from microarray analyses showed that the expression of several genes related to cell wall biosynthesis and cell wall modification, including the AGPs, was highly downregulated in the absence of $\mathrm{B}$, and vice versa [54]. The mechanism by which the cell signals $B$ availability to the nucleus remains unknown and will need to be studied further in order to be fully understood. However, it is clear from previous studies that B plays an essential role in the expression of cell wall-related genes responsible for maintaining the structural organization of the cell wall. It may further be speculated that $B$ is the key regulatory factor in determining the availability of AGPs, and consequently commencing the cellular signals necessary for the induction of somatic embryogenesis mainly through cellular communications (Figure 2). At present, no information is available on the $\mathrm{B}$ concentration required for the optimal expression levels of AGPs, which may, in turn, induce somatic embryogenesis. Further study whereby embryogenic calli are screened for the AGP expression levels in response to the varied B concentrations is certainly warranted to answer this biological question and may be best carried out using cotton as the model system for this work (Figure 3).

\section{Boron Provokes Stress-Mediated Signalling Pathways during Embryogenesis}

Boron plays a major role in the regulation of somatic embryogenesis by triggering stress-mediated pathways. Minimal B supply switches on many genetic and/or cellular transfactors responsible for the induction of somatic embryogenesis and has been considered to be dependent on the B transportation in the cell. With minimal to optimal B concentrations, AtNIP channel proteins, as discussed previously, play important role in $\mathrm{B}$ transportation and regulate its concentration inside the cell. However, in toxic concentrations, B is transported into the cell mainly through passive diffusion [55-57] and, as a result, may negatively affect embryogenic potential. Tolerance levels to the toxic B concentrations $(>1 \mathrm{mM})$ could be estimated by measuring the expression level of boron excess tolerant 1 gene, at least in rice [58], or its homolog in other systems. As B plays a vital role in cellular architecture mainly through cell wall organization, there may be concerns if the minimal $\mathrm{B}$ concentration may have an adverse effect on the cellular structure and related metabolic processes. It has been shown that complete B depletion from the culture medium not only induced root development, but also remarkable callusing followed by somatic embryogenesis in carrot and cucumber species, respectively $[32,59]$. These results further strengthen our assumption that $\mathrm{B}$ stress led to the manipulation of the cellular microenvironment and further assisted in the cell regeneration.

What are the essential molecular components that get up-regulated (=manipulated) in response to the B stress in vitro prior to embryogenesis? Under conditions of minimal $\mathrm{B}$, the accumulation of chlorogenic and caffeic acids has shown to result in inhibited IAA oxidase activity, leading to endogenous auxin accumulation [59-64]. It is well understood that the polar transport of auxin is essential for the establishment of bilateral symmetry in dicotyledonous somatic embryos, as well as in zygotic embryos [61, 63, 64]. If auxin is not present during development, somatic embryos may lose their bilateral symmetry during organ formation. Therefore, the threshold level of auxin has to be maintained inside the competent somatic cell for the acquisition of embryogenic potential, and B is important in the maintenance of this level of auxin inside the cell.

As stated above, auxin level is critical in the induction of somatic embryogenesis. It has been shown in the apical and subapical root sections of Arabidopsis that a 20-fold increase in IAA oxidase activity was displayed after B was withheld over minimal B-supplied cultures [65]. Thus, it is evident that minimal to no B supply increases the endogenous auxin level, and the altered-auxin level may further influence the downstream signalling for the induction of embryogenic potential (Figure 2). This is mainly considered through the change in the transcript levels of certain signalling genes 
responsible for the induction of somatic embryos. For example, enhanced endogenous level of auxin upregulates the expression of the somatic embryo receptor kinase (SERK) gene, somatic embryo-related factor (SERF), and $\mathrm{Ca}^{2+}$ ion channel-mediated regulatory gene expression, all reported earlier to be essential for somatic embryogenesis [66]. Early auxin-inducible genes in wheat leaf bases, including TaSERKs, are involved in somatic embryogenesis and decreased significantly upon auxin depletion [67]. Thus, it may be concluded that B (indirectly) can alter the expression of hormone-regulating genes and various other gene(s) which have an established role in somatic embryogenesis (Figure 2). Although it is uncertain how much B concentration is required initially and even in later stages of development for an absolute induction of embryogenic potential, it may be suggested that for precise induction of somatic embryogenesis in vitro, initially minimal B is required, and subsequently may also be culture stage specific (Figures 1 and 3). This could perhaps be best explained in the model system Gossypium, where the somatic embryogenesis occurs in three major stages (Figure 3). At the initial callus induction phase, high endogenous auxin is required and may be maintained either by the supply of exogenous auxin or by a minimal concentration of B exerting a stress condition. Later stages of embryogenesis require relatively low levels of auxin as a very high endogenous level may also inhibit somatic embryogenesis. Therefore, the low level of auxin can be maintained by the complete removal of exogenous auxin, and also by the supplementation of an optimal to maximal concentration of B in the culture medium, which would reduce the endogenous auxin level (Figures 3(b) and 3(c)). The latter may be considered to be more promising for the precise manipulation of auxin during the late embryogenic callus induction phase.

As noted elsewhere, at the molecular level, auxin plays an important role in the reprogramming of gene expression in a somatic cell for its induction into a somatic embryo, possibly through DNA methylation and chromatin remodelling [68] (Figure 2). The importance of the latter may be suggested by an increase in the expression of other signalling gene(s) responsible for somatic embryo induction. Boron stress also has a direct impact on levels of abscisic acid (ABA) and ethylene, both of which help to provide favorable conditions for the induction of somatic embryogenesis. The role of $\mathrm{ABA}$ in stress-induced somatic embryogenesis has been investigated [69], and it is known that B stress has significant role in increasing ABA level per se [59] (Figure 2). Thus, it is in this manner that $\mathrm{B}$ indirectly influences the ABAmediated signalling necessary for somatic embryogenesis. Mashayekhi and Neumann 2006 [59] have also shown the influence of B on embryo development through variation of the phytohormone system in the developing embryo.

Boron deficiency in somatic cells can also lead to accumulation of oxidative free radicals in somatic cells, which can affect membrane function [70] and embryo development within these cells. Moreover, the WRKY transcription factor which has been suggested to play important roles in the regulation of transcriptional reprogramming associated with plant stress responses including embryogenesis and abscisic acid signalling pathway is highly expressed in response of minimal B concentration [71-74]. It may be reasonably proposed here that expression of this WRKY transcription factor family gene affects and ultimately plays a regulatory role in somatic embryogenesis (Figure 2). However, the precise mechanism of the regulation of this pathway is subject to future research. Boron also plays a significant role in the expression of the mitochondrial alternative oxidase (AOX) gene, which is a gene generally expressed under Bdeficient conditions [75]. The AOX gene family has been shown to play a crucial role in somatic embryogenesis, as illustrated by previous work with carrot [76] (Figure 2). It was observed that the carrot AOX genes (DcAOXla and DcAOX2a) showed upregulation during initiation of somatic embryogenesis [76], thus contributing to the hypothesis that B affects AOX activity and supports the metabolic reorganization that is essential for cell restructuring and de novo differentiation.

\section{Conclusion}

The present study illustrates the importance of the B responsive gene network in the induction of somatic embryogenesis and suggests the basis for the molecular mechanisms involved in embryogenesis. We provide clues here for the direct or indirect role of $\mathrm{B}$ in somatic embryogenesis, explaining the molecular changes highlighting cellular mechanisms promoting the conversion of normal cells into embryogenic cell. Notably, the majority of B-mediated processes are diagnosed as having become enhanced during embryogenesis in different tissue types, as opposed to being a result of system-wide phenomena per se. This suggestion that expression of embryogenesis-related genes was primarily concomitant with B-mediated signalling pathways is bolstered by the remarkable observation that in independent embryogenesis events, taking place in different systems, this led to the expression of parallel signalling genes. Although this is true at the level of cellular processes, or perhaps metabolism, it is clear that the genesis of these similarities is only partially congruent at the genetic level. That is, different sets of embryogenesis-related genes are up-regulated accompanying only selected plant species/cultivars making the phenomenon highly genotype dependent, and without any precedent. Thus, an exciting prospect for future work will be to dissect this physiological transformation of somatic cells into its responsible constituent genes and to learn the system-wide mutational basis of their altered regulation or function.

\section{Acknowledgments}

The authors are thankful to Professor Jonathan F. Wendel and Kara Grupp, Iowa State University, USA for their suggestions in the preparation of this paper. The authors also thank the Department of Science and Technology (DST), Government of India, and Council of Scientific and Industrial Research (CSIR), Government of India for the financial support to carry out this cotton regeneration work. 


\section{References}

[1] S. Arnold, I. Sabala, P. Bozhkov, J. Dyachok, and L. Filonova, "Developmental pathways of somatic embryogenesis," Plant Cell, Tissue and Organ Culture, vol. 69, no. 3, pp. 233-249, 2002.

[2] J. Reinert, "Untersuchungen über die morphogenese an gewebenkulturen," Berichte der Deutschen Botanischen GesellschaftGes, vol. 71, p. 15, 1958.

[3] F. Steward, M. Mapes, and K. Hears, "Growth and organized development of cultured cells. II. Growth and division of freely suspended cells," American Journal of Botany, vol. 45, pp. 705708, 1958.

[4] O. Faure, W. Dewitte, A. Nougarède, and H. Van Onckelen, "Precociously germinating somatic embryos of Vitis vinifera have lower ABA and IAA levels than their germinating zygotic counterparts," Physiologia Plantarum, vol. 102, no. 4, pp. 591595,1998

[5] D. J. Gray, M. E. Compton, R. C. Harrell, and D. J. Cantliffe, "Somatic embryogenesis and the technology of synthetic seed," in Somatic Embryogenesis and Synthetic Seed I. Biotechnology in Agriculture and Forestry, Y. P. S. Bajaj, Ed., vol. 30, pp. 126-151, Springer-Verlag, Berlin, Germany, 1995.

[6] M. A. J. Toonen and S. C. De Vries, "Initiation of somatic embryos from single cells," in Embryogenesis: The Generation of a Plant, T. L. Wang and A. Cuming, Eds., pp. 173-189, Bios Scientific Publishers, Oxford, UK, 1996.

[7] D. Dudits, L. Bogre, and J. Gyorgyey, "Molecular and cellular approaches to the analysis of plant embryo development from somatic cells in vitro," Journal of Cell Science, vol. 99, no. 3, pp. 473-482, 1991.

[8] D. Dudits, J. Györgyey, L. B. Bögre, and L. Bakó, "Molecular biology of somatic embryogenesis," in In Vitro Embryogenesis In Plants, T. A. Thorpe, Ed., vol. 267-308, Kluwer Academic Publishers, Dordrecht, The Netherlands, 1995.

[9] S. Davletova, T. Mészáros, P. Miskolczi et al., "Auxin and heat shock activation of a novel member of the calmodulin like domain protein kinase gene family in cultured alfalfa cells," Journal of Experimental Botany, vol. 52, no. 355, pp. 215-221, 2001.

[10] J. Györgyey, A. Gartner, K. Németh et al., "Alfalfa heat shock genes are differentially expressed during somatic embryogenesis," Plant Molecular Biology, vol. 16, no. 6, pp. 999-1007, 1991.

[11] J. D. Cohen and R. S. Bandurski, "The bound auxins: protection of indole-3-acetic acid from peroxidase-catalyzed oxidation," Planta, vol. 139, no. 3, pp. 203-208, 1978.

[12] W. M. Dugger, "Boron in plant metabolism," in in Encyclopedia of Plant Physiology, A. Lauchli and L. Bieleski, Eds., vol. 15B, pp. 626-650, New Series, Springer, Berlin, Germany, 1983.

[13] H. Marschner, Mineral Nutrition of Higher Plants, Academic Press, London, UK, 2002.

[14] J. G. Paul, R. O. Nable, A. W. H. Lake, M. A. Materne, and A. J. Rathjen, "Response of annual medics (Medicago ssp.) and field peas (Pisum sativum) to high concentrations of boron: genetic variation and mechanism of tolerance," Australian Journal of Agricultural Research, vol. 43, no. 1, pp. 203-213, 1992.

[15] P. H. Brown and H. Hu, "Does boron play only a structural role in the growing tissues of higher plants?" Plant and Soil, vol. 196, no. 2, pp. 211-215, 1997.

[16] D. G. Blevins and K. M. Lukaszewski, "Boron in plant structure and function," Annual Review of Plant Biology, vol. 49, pp. 481-500, 1998.
[17] W. D. Loomis and R. W. Durst, "Chemistry and biology of boron," BioFactors, vol. 3, no. 4, pp. 229-239, 1992.

[18] T. Tanada, "Localization of boron in membranes," Journal of Plant and Nutrition, vol. 6, no. 9, pp. 743-749, 1983.

[19] D. H. Lewis, "Are there inter-relations between the metabolic role of boron, synthesis of phenolic phytoalexins and the germination of pollen?" New Phytologist, vol. 84, no. 2, pp. 261$270,1980$.

[20] R. Watanabe, W. J. McIlrath, J. Skok, W. Chorney, and S. $\mathrm{H}$. Wender, "Accumulation of scopoletin glucoside in borondeficient tobacco leaves," Archives of Biochemistry and Biophysics, vol. 94, no. 2, pp. 241-243, 1961.

[21] B. Dell and L. Huang, "Physiological response of plants to low boron," Plant and Soil, vol. 193, no. 1-2, pp. 103-120, 1997.

[22] A. H. Ali and B. C. Jarvis, "Effect of auxin and boron on nucleic acid metabolism and cell division during adventitious root regeneration," New Phytologist, vol. 108, no. 4, pp. 383$391,1988$.

[23] M. S. Cohen and L. S. Albert, "Autoradiographic examination of intact boron deficient squash roots treated with tritiated thymidine," Plant Physiology, vol. 54, no. 5, pp. 766-768, 1974.

[24] H. G. Gauch and W. M. Dugger, "The role of boron in the translocation of sucrose," Plant Physiology, vol. 28, no. 3, pp. 457-466, 1953.

[25] T. Matoh and M. Kobayashi, "Boron and calcium, essential inorganic constituents of pectic polysaccharides in higher plant cell walls," Journal of Plant Research, vol. 111, no. 1101, pp. 179-190, 1998.

[26] L. Coke and W. J. Whittington, "The role of boron in plant growth: IV. Interrelationships between boron and indol-3ylacetic acid in the metabolism of bean radicles," Journal of Experimental Botany, vol. 19, no. 2, pp. 295-308, 1968.

[27] B. C. Jarvis, S. Yasmin, and M. T. Coleman, "RNA and protein metabolism during adventitious root formation in stem cuttings of Phaseolus aureus," Physiologia Plantarum, vol. 64, no. 1, pp. 53-59, 1985.

[28] R. Kastori and N. Petrovic, "Effect of boron on nitrate reductases in tobacco leaves and roots," Molecular Genomics and Genetics, vol. 236, pp. 203-208, 1989.

[29] J. M. Ruiz, M. Baghour, G. Bretones, A. Belakbir, and L. Romero, "Nitrogen metabolism in tobacco plants (Nicotiana tabacum $L$ ): role of boron as a possible regulatory factor," International Journal of Plant Sciences, vol. 159, no. 1, pp. 121126, 1998.

[30] H. Hu and P. H. Brown, "Localization of boron in cell walls of squash and tobacco and its association with pectin. Evidence for a structural role of boron in the cell wall," Plant Physiology, vol. 105, no. 2, pp. 681-689, 1994.

[31] H. Pfeffer, F. Dannel, and V. Römheld, "Boron compartmentation in roots of sunflower plants of different boron status: a study using the stable isotopes $10 \mathrm{~B}$ and $11 \mathrm{~B}$ adopting two independent approaches," Physiologia Plantarum, vol. 113, no. 3, pp. 346-351, 2001.

[32] K. Mashayekhi, M. Sharifani, M. Shahsavand, and H. Kalati, "Induction of somatic embryogenesis in absence of exogenous auxin in cucumber (Cucumis sativus L.)," International Journal of Plant Production, vol. 2, no. 2, pp. 163-166, 2008.

[33] N. Renukdas, M. L. Mohan, S. S. Khuspe, and S. K. Rawal, "Influence of boron on somatic embryogenesis in papaya," Biologia Plantarum, vol. 47, no. 1, pp. 129-132, 2004.

[34] N. A. Sahasrabudhe, M. Nandi, and R. A. Bahulikar, "Influence of boric acid on somatic embryogenesis of a cytosterile line of indica rice," Plant Cell, Tissue and Organ Culture, vol. 58, no. 1, pp. 73-75, 1999. 
[35] U. Behrendt, "Entwicklungsbiologische untersuchungen zur somatischen embryogenese bei der europischen lrche (Larix decidua MILL.)," in Mathematisch-Natur-wissenschaftliche Fakultt I der, vol. 125, Humboldt-Universitatzu, Berlin, Germany, 1994.

[36] U. Behrendt and K. Zoglauer, "Boron controls suspensor development in embryogenic cultures of Larix decidua," Physiologia Plantarum, vol. 97, no. 2, pp. 321-326, 1996.

[37] T. Murashige and F. Skoog, "A revised medium for rapid growth and bioassays with tobacco tissue cultures," Physiologia Plantarum, vol. 15, no. 3, pp. 473-497, 1962.

[38] B. Chaudhary, S. Kumar, K. V. S. K. Prasad, G. S. Oinam, P. K. Burma, and D. Pental, "Slow desiccation leads to highfrequency shoot recovery from transformed somatic embryos of cotton (Gossypium hirsutum L. cv. Coker 310 FR)," Plant Cell Reports, vol. 21, no. 10, pp. 955-960, 2003.

[39] K. L. Fitzpatrick and R. J. Reid, "The involvement of aquaglyceroporins in transport of boron in barley roots," Plant, Cell and Environment, vol. 32, no. 10, pp. 1357-1365, 2009.

[40] N. Mitani-Ueno, N. Yamaji, F. J. Zhao, and J. F. Ma, "The aromatic/arginine selectivity filter of NIP aquaporins plays a critical role in substrate selectivity for silicon, boron, and arsenic," Journal of Experimental Botany, vol. 62, no. 12, pp. 4391-4398, 2011.

[41] I. S. Wallace and D. M. Roberts, "Distinct transport selectivity of two structural subclasses of the nodulin-like intrinsic protein family of plant aquaglyceroporin channel," Biochemistry, vol. 44, no. 51, pp. 16826-16834, 2005.

[42] V. T. Ciavatta, R. Morillon, G. S. Pullman, M. J. Chrispeels, and J. Cairney, "An aquaglyceroporin is abundantly expressed early in the development of the suspensor and the embryo proper of loblolly pine," Plant Physiology, vol. 127, no. 4, pp. 1556-1567, 2001.

[43] J. Takano, M. Wada, U. Ludewig, G. Schaaf, N. Von Wirén, and T. Fujiwara, "The Arabidopsis major intrinsic protein NIP5;1 is essential for efficient boron uptake and plant development under boron limitation," Plant Cell, vol. 18, no. 6, pp. 14981509, 2006.

[44] M. Tanaka, J. Takano, Y. Chiba et al., "Boron-dependent degradation of NIP5,1 mRNA for acclimation to excess boron conditions in Arabidopsis," The Plant Cell, vol. 23, no. 9, pp. 3547-3559, 2011.

[45] P. F. McCabe, T. A. Valentine, L. S. Forsberg, and R. I. Pennell, "Soluble signals from cells identified at the cell wall establish a developmental pathway in carrot," Plant Cell, vol. 9, no. 12, pp. 2225-2241, 1998.

[46] M. Anna and A. Eugene, "The multiple roles of arabinogalactan proteins in plant development," Plant Physiology, vol. 122, no. 1, pp. 3-9, 2000.

[47] H. S. Sardar, J. Yang, and A. M. Showalter, "Molecular interactions of arabinogalactan proteins with cortical microtubules and F-actin in bright yellow-2 tobacco cultured cells," Plant Physiology, vol. 142, no. 4, pp. 1469-1479, 2006.

[48] S. E. Wyatts and N. C. Carpita, "The plant cytoskelet on-cellwall continuum," Trends in Cell Biology, vol. 3, no. 122, pp. 413-417, 1994.

[49] M. Kreuger and G. J. van Holst, "Arabinogalactan proteins are essential in somatic embryogenesis of Daucus carota L.", Planta, vol. 189, no. 2, pp. 243-248, 1993.

[50] N. J. Stacey, K. Roberts, and J. P. Knox, "Patterns of expression of the JIM4 arabinogalactan-protein epitope in cell cultures and during somatic embryogenesis in Daucus carota L.", Planta, vol. 180, no. 2, pp. 285-292, 1990.
[51] A. Chapman, A. S. Blervacq, J. Vasseur, and J. L. Hilbert, "Arabinogalactan-proteins in Cichorium somatic embryogenesis: effect of $\beta$-glucosyl Yariv reagent and epitope localisation during embryo development," Planta, vol. 211, no. 3, pp. 305$314,2000$.

[52] H. J. M. Thompson and J. P. Knox, "Stage-specific responses of embryogenic carrot cell suspension cultures to arabinogalactan protein-binding $\beta$-glucosyl Yariv reagent," Planta, vol. 205, no. 1, pp. 32-38, 1998.

[53] A. J. Van Hengel, Z. Tadesse, P. Immerzeel, H. Schols, A. Van Kammen, and S. C. De Vries, "N-acetylglucosamine and glucosamine-containing arabinogalactan proteins control somatic embryogenesis," Plant Physiology, vol. 125, no. 4, pp. 1880-1890, 2001.

[54] J. J. Camacho-Cristóbal, M. B. Herrera-Rodríguez, V. M. Beato et al., "The expression of several cell wall-related genes in Arabidopsis roots is down-regulated under boron deficiency," Environmental and Experimental Botany, vol. 63, no. 1-3, pp. 351-358, 2008.

[55] C. Dordas and P. H. Brown, "Evidence for channel mediated transport of boric acid in squash (Cucurbita pepo)," Plant and Soil, vol. 235, no. 1, pp. 95-103, 2001.

[56] C. Dordas, M. J. Chrispeels, and P. H. Brown, "Permeability and channel-mediated transport of boric acid across membrane vesicles isolated from squash roots," Plant Physiology, vol. 124, no. 3, pp. 1349-1361, 2000.

[57] J. C. R. Stangoulis, R. J. Reid, P. H. Brown, and R. D. Graham, "Kinetic analysis of boron transport in Chara," Planta, vol. 213, no. 1, pp. 142-146, 2001.

[58] K. Ochiai, A. Shimizu, Y. Okumoto, T. Fujiwara, and T. Matoh, "Suppression of a NAC-like transcription factor gene improves boron-toxicity tolerance in rice," Plant Physiology, vol. 156, no. 3, pp. 1457-1463, 2011.

[59] K. Mashayekhi and K. H. Neumann, "Effects of boron on somatic embryogenesis of Daucus carota," Plant Cell, Tissue and Organ Culture, vol. 84, no. 3, pp. 279-283, 2006.

[60] U. C. Gupta, "Boron," in Handbook of Plant Nutrition, A. V. Barker and D. J. Pilbean, Eds., pp. 241-277, Taylor and Francis Publications, Boca Raton, Fla, USA, 2006.

[61] C. M. Liu, Z. H. Xu, and N. H. Chua, "Auxin polar transport is essential for the establishment of bilateral symmetry during early plant embryogenesis," Plant Cell, vol. 5, no. 6, pp. 621630, 1993.

[62] F. LoSchiavo, L. Pitto, G. Giuliano et al., "DNA methylation of embryogenic carrot cell cultures and its variations as caused by mutation, differentiation, hormones and hypomethylating drugs," Theoretical and Applied Genetics, vol. 77, no. 3, pp. 325-331, 1989.

[63] F. M. Schiavone and T. J. Cooke, "A geometric analysis of somatic embryo formation in carrot cell cultures," Canadian Journal of Botany, vol. 63, no. 9, pp. 1573-1578, 1985.

[64] F. M. Schiavone and T. J. Cooke, "Unusual patterns of somatic embryogenesis in the domesticated carrot: developmental effects of exogenous auxins and auxin transport inhibitors," Cell Differentiation, vol. 21, no. 1, pp. 53-62, 1987.

[65] C. W. Bohnsack and L. S. Albert, "Early effectsof boron deficiency on Indoleacetic Acid Oxidase levelsof Squash root tips," Plant Physiology, vol. 59, no. 6, pp. 1047-1050, 1977.

[66] T. Takeda, H. Inose, and H. Matsuoka, "Stimulation of somatic embryogenesis in carrot cells by the addition of calcium," Biochemical Engineering Journal, vol. 14, no. 2, pp. 143-148, 2003.

[67] B. Singla, J. P. Khurana, and P. Khurana, "Characterization of three somatic embryogenesis receptor kinase genes from 
wheat, Triticum aestivum," Plant Cell Reports, vol. 27, no. 5, pp. 833-843, 2008.

[68] F. Zeng, X. Zhang, S. Jin et al., "Chromatin reorganization and endogenous auxin/cytokinin dynamic activity during somatic embryogenesis of cultured cotton cell," Plant Cell, Tissue and Organ Culture, vol. 90, no. 1, pp. 63-70, 2007.

[69] A. Kikuchi, N. Sanuki, K. Higashi, T. Koshiba, and H. Kamada, "Abscisic acid and stress treatment are essential for the acquisition of embryogenic competence by carrot somatic cells," Planta, vol. 223, no. 4, pp. 637-645, 2006.

[70] I. Cakmak and V. Römheld, "Boron deficiency-induced impairments of cellular functions in plants," Plant and Soil, vol. 193, no. 1-2, pp. 71-83, 1997.

[71] L. Chen, Y. Song, S. Li, L. Zhang, C. Zou, and D. Yu, "The role of WRKY transcription factors in plant abiotic stresses," Biochemica Biophysica Acta, vol. 1819, no. 2, pp. 120-128, 2012.

[72] I. Kasajima, Y. Ide, M. Yokota Hirai, and T. Fujiwara, "WRKY6 is involved in the response to boron deficiency in Arabidopsis thaliana," Physiologia plantarum, vol. 139, no. 1, pp. 80-92, 2010.

[73] M. Lagacé and D. P. Matton, "Characterization of a WRKY transcription factor expressed in late torpedo-stage embryos of Solanum chacoense," Planta, vol. 219, no. 1, pp. 185-189, 2004.

[74] X. Zou, J. R. Seemann, D. Neuman, and Q. J. Shen, “A WRKY gene from creosote bush encodes an activator of the abscisic acid signaling pathway," Journal of Biological Chemistry, vol. 279, no. 53, pp. 55770-55779, 2004.

[75] D. P. Maxwell, Y. Wang, and L. McIntosh, "The alternative oxidase lowers mitochondrial reactive oxygen production in plant cells," Proceedings of the National Academy of Sciences of the United States of America, vol. 96, no. 14, pp. 8271-8276, 1999.

[76] A. M. Frederico, M. D. Campos, H. G. Cardoso, J. Imani, and B. Arnholdt-Schmitt, "Alternative oxidase involvement in Daucus carota somatic embryogenesis," Physiologia Plantarum, vol. 137, no. 4, pp. 498-508, 2009. 

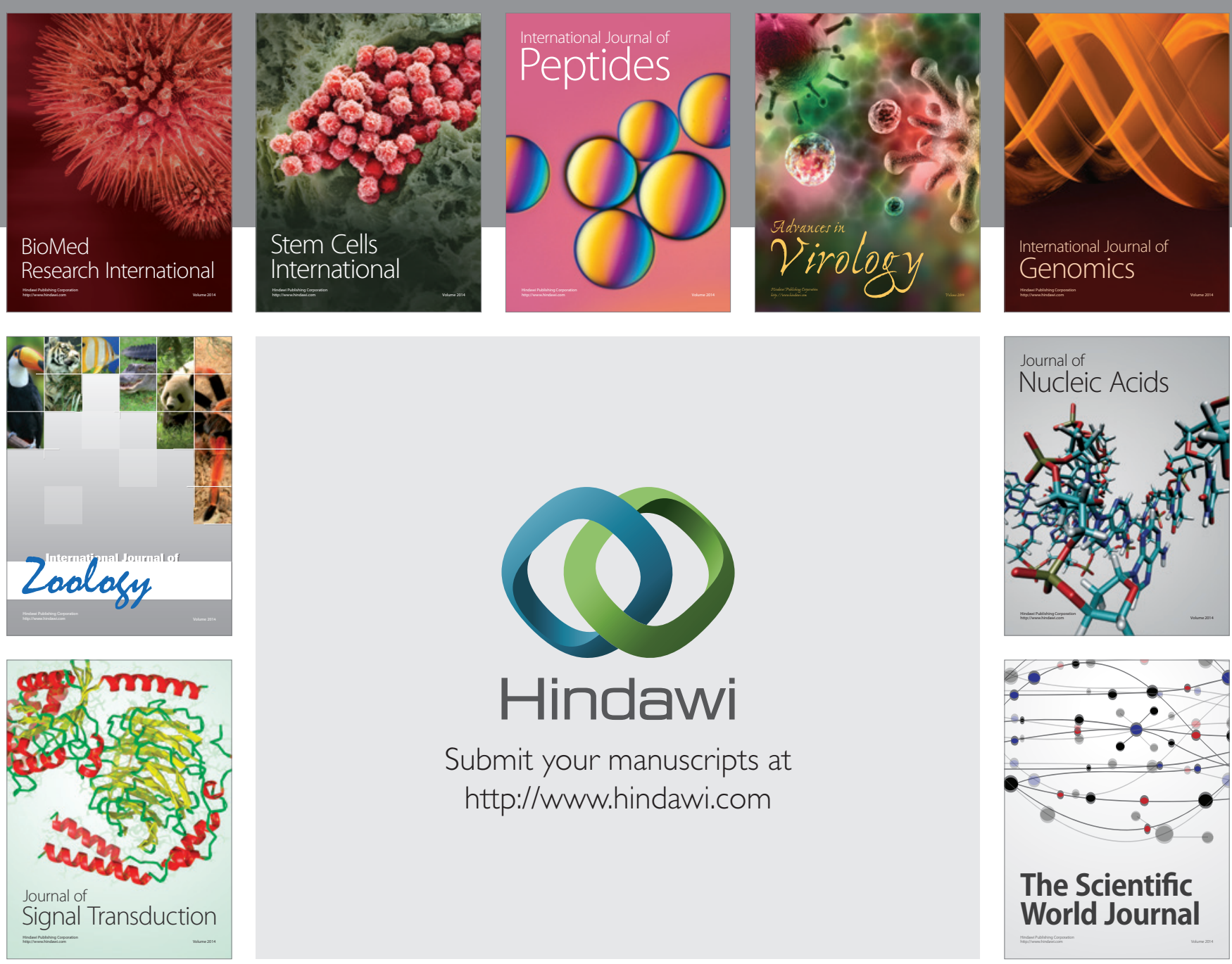

Submit your manuscripts at

http://www.hindawi.com
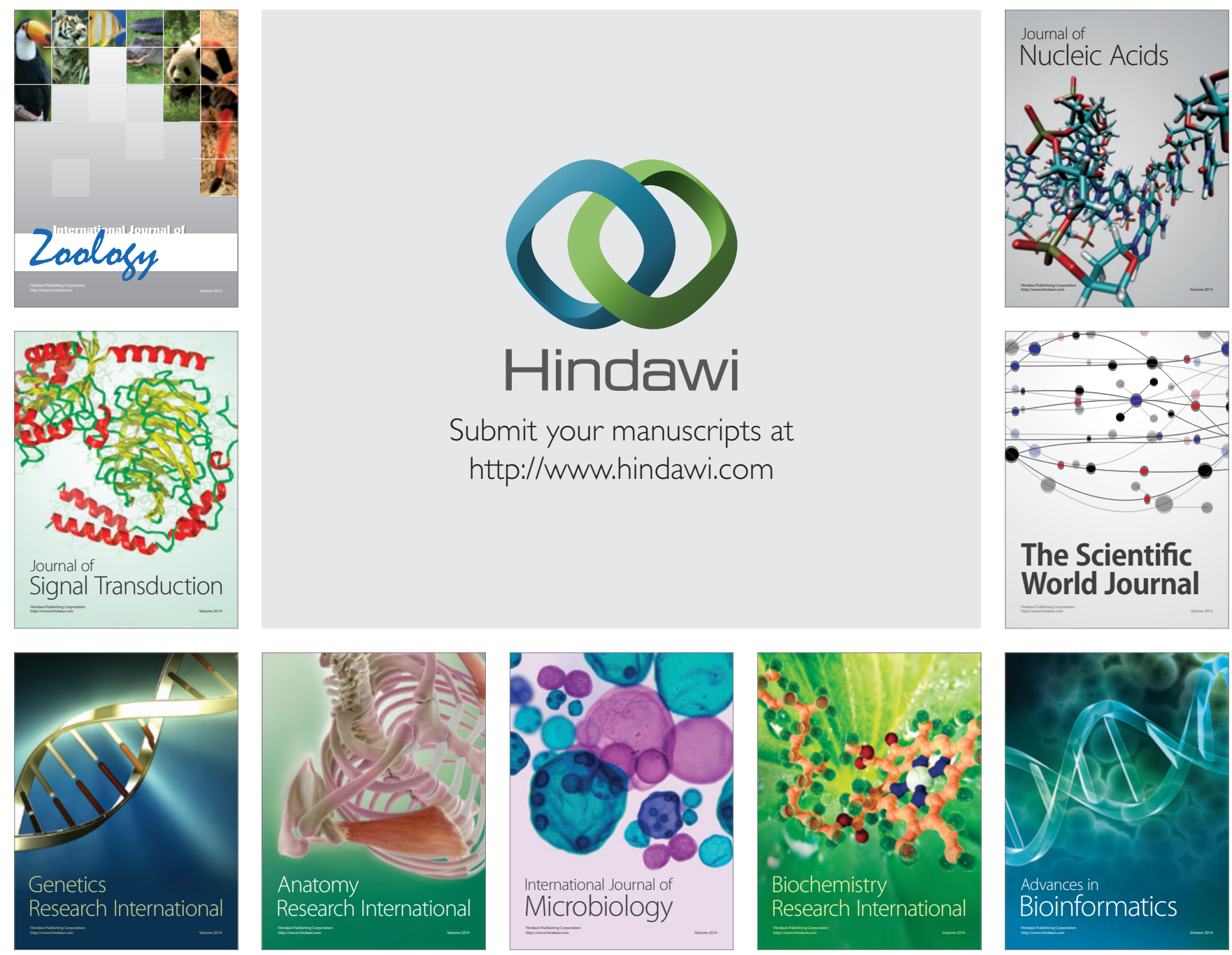

The Scientific World Journal
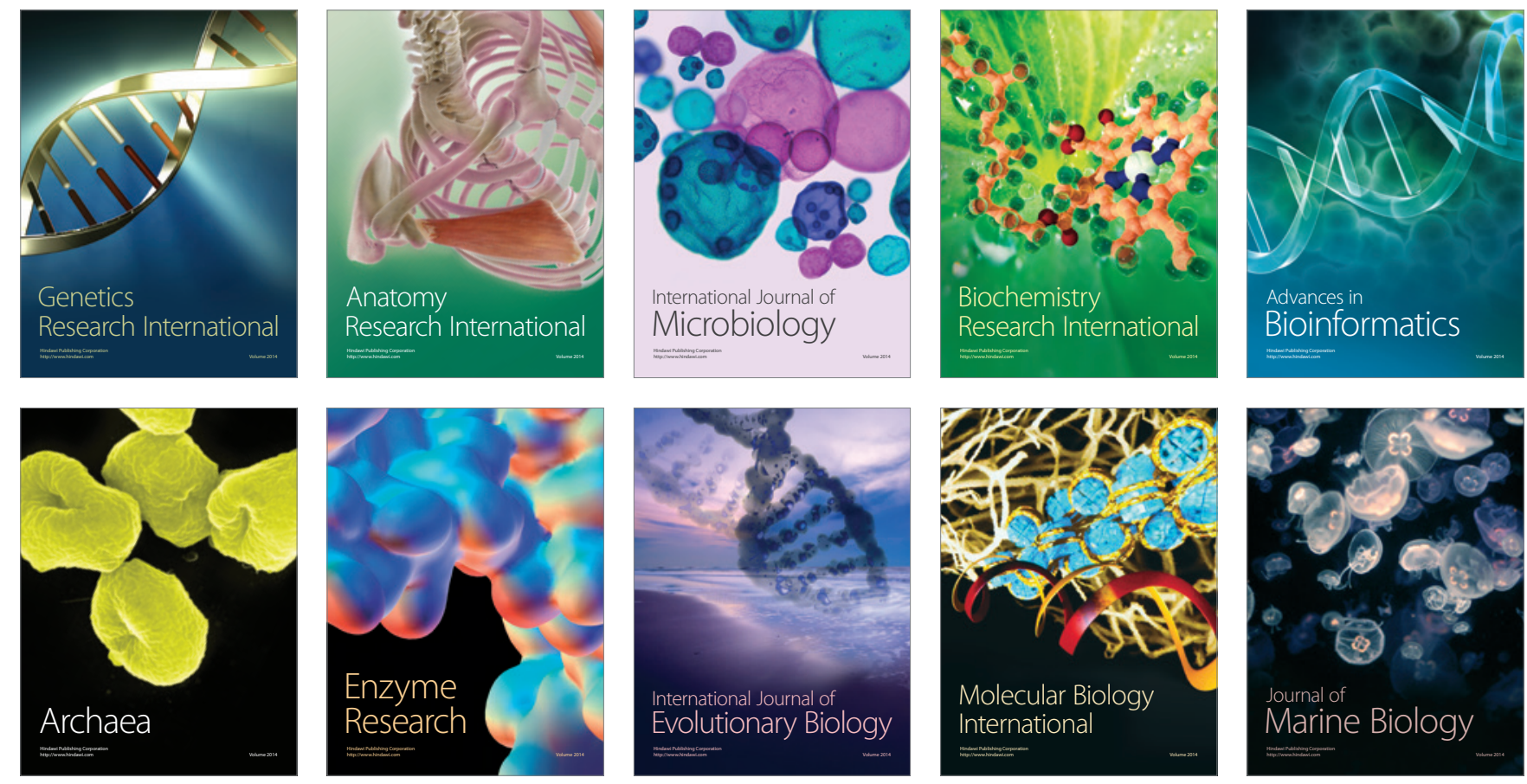